\title{
A planned study of the impact of B2C logistics service quality on shopper satisfaction and loyalty
}

\author{
DAVID B. GRANT* BERND PHILIPP**
}

\begin{abstract}
Purpose of the paper: This paper reports on an in-progress study of the impact of business to consumer (B2C) logistics service quality $(L S Q)$ on in-store shopper satisfaction and loyalty.

Methodology: A comparative research approach is being used across the UK, France and Germany to also investigate country-specific differences of consumer shopping behaviour and channel strategies. The first stage, in-line with a deliberate integrated supply chain approach, consists of structured in-depth interviews conducted with managers at the producer/retailer interface, e.g. producer category captains and retail category managers. This qualitative stage will be followed-up by a quantitative survey stage targeting consumers as shoppers to determine how their expectations of retail LSQ and associated activities influence their satisfaction and ongoing loyalty.

Findings: A broad literature review has generated over 40 variables of interest for both LSQ and loyalty, and almost 10 variables of satisfaction. This study will contribute theoretically by considering a B2C setting for $L S Q$, which is the final aspect of point of origin to point-of-consumption, whereas most general LSQ literature and LSQ's impact on customer satisfaction and loyalty has been dominated by business to business $(B 2 B)$ designs from pointof-origin to point of sale, that is they assume consumer expectations are a given or a different domain.

Research limitations: Although covering three major European grocery retail markets, this study might not be considered as representative, especially when adopting a world-wide perspective.

Practical implications: As this study emphasises consequences of B2C LSQ on downstream or consumer satisfaction and loyalty, rather than considering the upstream origins of related problems that dominate extant research, it will contribute practically by providing managers with an understanding of the components of LSQ considered critical by consumers.
\end{abstract}

* Best paper for the $17^{\text {th }}$ Toulon-Verona Conference "Excellence in services", Liverpool, United Kingdom, 28 and 29 August 2014.

Both authors contributed equally to this paper.

** Full Professor of Logistics Hull University Business School e-mail: d.grant@hull.ac.uk

*** Full Professor of Supply Chain Management, ESCE International Business School Paris e-mail: bernd.philipp@esce.fr

Sinergie, Italian Journal of Management n. 95, Settembre-Dicembre 2014, pp. 45-63 ISSN 0393-5108 - DOI 10.7433/s95.2014.05
Accettato nei Conference Proceeding: 30/06/2014 Valutato come best: $31 / 10 / 2014$ Accettato: 09/12/2014 
Originality of the paper: $L S Q$ in this study is considered to be a holistic concept and not limited to specific dimensions and trade-offs, for example on-shelf availability versus out-ofstock situations.

Key words: Logistics service quality (LSQ); business to consumer (B2C); retail logistics; satisfaction; loyalty; in-store logistics

\section{Introduction and Research Motivation}

Logistics service quality (LSQ), logistics performance, logistics service level or logistics value, which are often considered synonyms, are generally discussed in business to business B2B settings (Sharma et al., 1995). There are few contributions of research into LSQ directed towards the final customer, i.e. the consumer or shopper. Neglecting this aspect of LSQ is difficult to understand, which is important at two different levels. Firstly, the shopper represents a productive resource (Harris et al., 2001) as an important downstream supply chain member or logistician, carrying out logistics activities and tasks, weighing up LSQ with economic and noneconomic costs (burden, endeavours, inconvenience), confronted with typical supply chain decisions such as outsourcing logistics tasks - via home delivery and electronic shopping - or internalize them - via store-based, traditional shopping (Granzin et al., 1997; Teller et al., 2006; Teller et al., 2012). In other words, the consumer represents the final link in the point-of-origin to point-of-consumption definition of logistics (Grant, 2012).

Secondly, LSQ activities directed towards the consumer or shopper (LSQS) also act along a marketing axis: i.e. satisfaction and loyalty both on transaction-specific and on cumulative levels (Zhang et al., 2005), are not only influenced by product quality elements, but also by service-related dimensions building up the overall shopping experience. LSQS seems to be an important element in this context, influencing shopper satisfaction and loyalty which are two major variables in marketing research as they guarantee the company's competitive advantage (Innis and Lalonde, 1994).

This double role of the shopper, i.e. a downstream supply chain member and customer/consumer at the same time, justifies a dedicated conceptualization of LSQS. Consequently, a dedicated LSQS concept should mobilize both logistics/supply chain management (SCM) and marketing literature streams in an integrated manner, as any separation appears artificial in this context. Extant academic literature does not propose a holistic concept of LSQS yet, but only specific subsets such as on-shelf availability and out-of-stocks. In the same manner, existing literature stresses upon immediate shopper "reactions" or "reaction patterns" (Fernie and Grant, 2008; McKinnon et al., 2007; Meng et al., 2012), without explicitly tackling the cumulative/ long-run dimension of shopper satisfaction and loyalty.

Both the marketing and the logistics/SCM literature streams advise delimiting product categories for research purposes. Adopting the marketing approach, 
customer expectations vary across product categories (Thirumalai and Sinha, 2004; Mentzer et al., 2001), implying different satisfaction and loyalty levels according to the considered product category. In the same manner, according to logistics/ SCM literature, different 'logistics families' (Colin and Fabbe-Costes, 1995) follow different management constraints, and recent empirical work on in-store logistics and retail logistics has concentrated on specific categories such as health and beauty, dairy products, non-food retail (Grant and Fernie 2008; McKinnon et al., 2007; Meng et al., 2012). Thus, we consider it relevant to focus on the grocery sector, as "shopper logistics tasks and costs are higher compared to shopping endeavours for other product categories" (Teller et al. 2012, p. 59). We are excluding electronic shopping/home delivery/drive-to-collect in this particular study to understand complementary rather than substituting characteristics with regards to store-based shopping (Teller et al. 2012). Online shopping, despite still being marginal in terms of grocery market share, nevertheless has seen recent rapid growth and hence will be the focus of a future study considering the LSQS constructs and variable developed for this study for comparative purposes.

In 2000, $65 \%$ of European food retail sales were concentrated in the four big markets of France, UK, Germany and Italy (Perkins, 2001). Our comparative approach with regards to our three target countries (UK, France, Germany) might reveal significant differences, as consumer homogeneity versus heterogeneity should be considered as a complex interplay of factors rather than as two ends of a spectrum (Myers and Alexander, 2007). Concerning European retail structures and retail industry development we also observe heterogeneity (Perkins, 2001), justifying once again the need for country-specific LSQS design and conceptualization.

\section{Theoretical Background}

Based on our motivations above, the theoretical themes investigated in the literature include LSQ and consumer or shopper satisfaction and loyalty, and the retail grocery context of study in UK, France and Germany. Further, while we are excluding online or Internet grocery retailing in this study and are focusing only on in-store experiences, previous work that has investigated LSQ for such retailing and home delivery will also be discussed as it pertains to this study.

\section{Consumer LSQ, satisfaction and loyalty}

General LSQ concepts are usually investigated in B2B settings; there are few contributions dedicated to B2C contexts. Thus, discrete LSQS concepts are usually derived from inter-company LSQ concepts and are often referred to as the 'seven rights': the right amount, of the right product, at the right place, at the right time, in the right condition, at the right price, with the right information (Mentzer et al., 1999, 2001; Bienstock et al., 2008). Within B2B settings, several distinctive characteristics have been developed so far for the LSQ concept. The first one 
distinguishes three typologies: outcome; process; and structure/potential/functional (Thai, 2013; Göpfert and Wehberg, 1995). This conceptualization is close to the traditional construct of company performance. The second one develops the LSQ concept's focus: either oriented towards the customer/consumer and his/her evaluations or perceptions - 'subjective quality' - or towards the service provider in a more industrial view (Saura et al., 2008; Thai, 2013).

Following Grant (2003, p. 106), the overarching framework for customer/ consumer/ shopper satisfaction is the expectancy-disconfirmation paradigm where shoppers develop expectations prior to a product or service experience, and then either confirm or disconfirm those expectations afterwards. This comparison refers to product or service performance, which has business implications for a retailer, producer or other supplier providing the product or service.

But, although researchers have examined the influence of general service quality on consumer satisfaction and loyalty (Parasuram et al., 1985; Danaher and Mattson, 1994; Bei and Chiao, 2001), little research has been conducted on the specific issue of LSQS. End consumer satisfaction and loyalty are influenced by a wide set of factors or drivers occurring at the different moments within the consumption experience (Liu et al., 2008). Together with other factors stemming from marketing and other business domains, LSQS elements impact both consumer satisfaction and loyalty (Sharma et al., 1995).

The few scientific contributions once again relate to B2B settings (e.g. Saura et al., 2008). However, Bouzaabia et al. (2013), transferred both the concept and scales of Mentzer et al. $(1999,2001)$ to a B2C setting by presenting another distinctive characteristics of what now can be considered an LSQS concept: operational versus relational dimensions. They empirically examined the predictor role of LSQS on satisfaction and loyalty however only two countries were considered in their study Tunisia and Romania - and no distinction was discussed between transactionspecific and cumulative levels of satisfaction and loyalty. Thus, both their concept and scale are incomplete and not holistic (Mentzer et al., 1999, 2001).

\section{Context of study}

The context of this study is the three European countries of the UK, Germany and France. We focus on Germany as it is Europe's largest retail food market with a population of 82 million people and food retail sales in 2012 of 186.7 billion Euros (Access 6, 2013). By comparison, the UK retail food market was $£ 169.7$ billion in 2013 with hypermarkets, superstores and small supermarkets accounting for $64.2 \%$ of this total. Retail food sales in France were 208 billion Euros in 2012 with hypermarkets and supermarkets representing $75 \%$ of the market (IGD, 2014). Both the UK and France have populations in the 60 million plus range.

In Germany, structural changes in the market over the last ten years have seen an intensifying concentration of the top five food retailing companies as shown in Table 1. Further, the German retail food market has long been dominated by discounters such as Aldi and Lidl (part of the Schwarz Group). Discounters still have $43.9 \%$ of the market (IGD, 2014, Thomasson, 2014) - a huge share when 
compared to $5.6 \%$ in the UK (or $£ 9.5$ billion in sales) and $15 \%$ in France (or 31.2 billion Euros in sales).

Tab 1: German grocery retail market share 2012

\begin{tabular}{|lc|}
\hline Retailer & Grocery retail market share 2012 \\
\hline Edeka & $16.4 \%$ \\
Rewe Group & $11.7 \%$ \\
Schwarz Group & $10.6 \%$ \\
Aldi & $9.3 \%$ \\
Metro (Real) & $7.0 \%$ \\
Others & $45.0 \%$ \\
\hline
\end{tabular}

Source: Access 6 (2013)

Pressure from discount competition has forced German retail food chains to lower prices in order to compete and maintain or even gain customers. Thus, extensive price competition almost offers no opportunity to pass along increased costs, such as logistics costs, to final consumers (Klumpp and Jasper, 2008). Accordingly, German food retailers and in particular discounters operate on very small average profit margins of around 1\% compared to higher margins found in France (5\%), the Netherlands (6\%), and Spain and the UK (6-8\%).

\section{Lessons from online or Internet grocery retailing}

The Internet has risen in importance and acceptance among firms and consumers to conduct business (Xing and Grant, 2006). Further, online grocery shopping has been presented as a promising additional channel for future sales and as a medium to create customer loyalty (Fernie and Grant, 2008). Lastly, consumers' ability to purchase their food needs over the Internet and have them delivered to their homes represents a service innovation in retailing (Kämäräinen and Punakivi, 2002).

However, while Germany is one of the largest retail food markets in Europe, it significantly lags behind in online food retailing when compared to the driving force in Europe, the UK, as well as France. Online food retailing market share in 2012 was about 3.8\% ( $£ 6.5$ billion) in the UK and 2.4\% (5 billion Euros) in France, but only about $0.06 \%$ (1.1 billion Euros) in Germany (IGD, 2014). Another reason for the gaps across similar countries is that each country has different food retail markets. Unlike Germany, the UK and France have highly consolidated food markets with less price competition and fewer hard discounters, and this allows 'high-value service' retail concepts such as online grocery (Grant, 2012).

The rise of $\mathrm{B} 2 \mathrm{C}$ e-commerce has introduced challenges in retail logistics, especially in the physical distribution to the final customer. In traditional retail businesses products are selected and taken home by the consumers from the local store at any time they want. In contrast, e-commerce enables consumers to select the products online and have them delivered to their doorstep (Xing et al., 2011). Additional operations of order-picking, packaging and delivery have to be performed by the retailers which are expensive to carry out (Kämäräinen and 
Punakivi, 2002). Thus, the responsibility for the fulfilment process has switched from the consumer to the retailer.

A certain customer base is crucial to conduct online grocery retailing to generate sales and thus turn this business model into profitability. Therefore, it is essential to convince customers of the added value this business model offers (Teller et al., 2006, 2012). Creating trust and thus customer loyalty from satisfied purchase experiences is also of great importance to the grocery retailers to convince customers.

Fulfilment issues are concentrated mainly on customer satisfaction and economic aspects in terms of effective order processing and delivery operations to the final customer. In particular, effective and quick deliveries are an essential part in gaining customer loyalty and fulfilment operations help to establish a superior service and differentiate from the competition (Xing and Grant, 2006).

\section{Research Gaps and Propositions}

Based on the foregoing review of theory and literature and research gaps, we have posited three research objectives and their underlying research questions as follows.

RO1: Measure the impact of LSQS perceptions on shopper satisfaction and loyalty, both on transaction-specific and cumulative levels, by using a holistic concept and measure scale for LSQS, developed from both logistics/SCM and marketing literature streams.

RQ1: How can the relationship between LSQS perceptions and shopper satisfaction and loyalty be characterised, both on transaction-specific and cumulative levels?

RO2: Compare perceptions of supply chain members (producer category captains, retail category managers) and shoppers with regards to LSQS.

RQ2: Is there congruence or hiatus between perceptions of supply chain members (producer category captains, retail category managers) and shoppers with regards to LSQS?

RO3: Investigate country-specific differences (UK, France, Germany) of LSQS perceptions.

RQ3: Are there country-specific differences of LSQS perceptions between the UK, France and/or Germany? 


\section{Methodology}

This study is undertaking a fresh and new approach to the phenomena of interest: LSQS. Accordingly, to ensure construct, internal and external validity this study is using Churchill's (1979) two-stage framework for the development and validation of items and constructs in marketing; Dunn et al., (1994) subsequently adopted this framework for logistics and thus it has been proven robust in both disciplines.

In the first stage the domain of the latent constructs must be specified and confirmed (Churchill, 1979; Dunn et al., 1994). In this study the a priori constructs are consumer LSQ, satisfaction and loyalty and the first stage for this study, in-line with a deliberate integrated and holistic supply chain approach, consists of structured in-depth interviews conducted with managers at the producer/retailer interface, e.g. producer category captains and retail category managers.

In the second stage, manifest variables or items related to the latent constructs must be generated and then tested and purified via major empirical research. This study will follow-up the first qualitative stage with a quantitative survey stage targeting consumers as shoppers to verify their expectations of retail grocery LSQS and related activities relate to their satisfaction and ongoing loyalty.

This two-stage proceeding seems relevant, as major discrepancies or gaps are frequent between shopper/ consumer expectations, on the one hand, and, on the other, executive perceptions of shopper/consumer expectations. Indeed, Parasuraman et al. (1985) identified within their general service quality model this so-called 'gap 1' susceptible to having an impact on shopper's/consumer's evaluation of service quality, and consecutively on his/her satisfaction and loyalty levels.

Descriptive statistics involving data frequencies, means, standard deviations and cross-tabulations will be performed for all data. Exploratory factor analysis (EFA) will be used to examine the latent constructs and internal consistency of individual items. Finally, confirmatory factor analysis (CFA) and structural equation modelling (SEM) will be used to determine the validity, reliability, and relationships among the items and latent constructs.

\section{Conceptual Model}

Figure 1 shows our conceptual model wherein logistics service quality (LSQS) directly affects satisfaction (SATIS), which in turn directly affects loyalty (LOYAL). Alternatively, it may be that satisfaction is implicit and LSQS may directly affect LOYAL without a direct effect on SATIS. We now turn to discussing the development of the constructs from the literature using the Churchill (1979) framework. 
Fig. 1: Conceptual Model

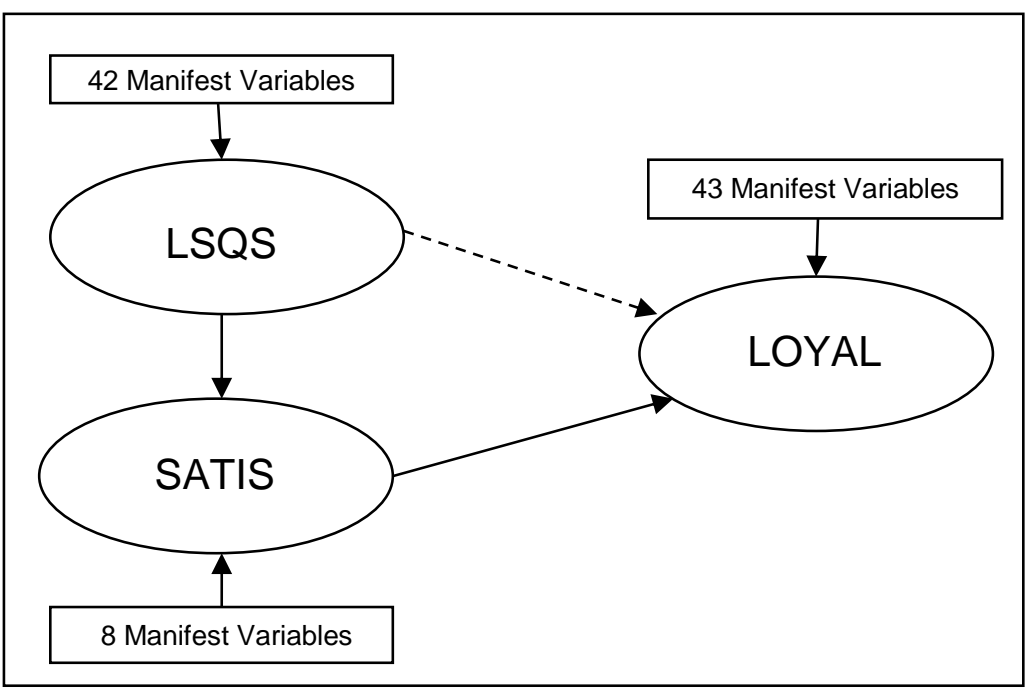

Source: Authors

\section{The LSQS construct}

For most authors proposing LSQS constructs and measures, the general SERVQUAL scale elaborated by Parasuraman et al. (1988) represents a useful starting point, although it is not completely adapted to logistics features as it was designed primarily for consumer services such as fast-food and banking. Reviewing the literature related to B2B settings, Saura et al. (2008) have identified relevant measures of the LSQ construct as follows: timeliness, condition and accuracy of the order, quality of information, availability and quality of contact personnel. Amongst these elements, timeliness or on time delivery has revealed to be the most important one (Rahman, 2006; Mentzer et al., 2001; Bienstock et al., 1997; Novack et al., 1994; La Londe and Zinszer, 1991; Perrault and Russ, 1976).

As noted above, Bouzaabia et al. (2013) have derived, from B2B literature, measures for a B2C setting. Both Saura et al. (2008) and Bouzaabia et al. (2013) refer to Parasuraman's et al. (1988) general SERVQUAL scale, but they do both not consider Dabholkar's et al. (1996) contribution in retail service quality scale.

We apply the 'seven rights' of the logistics service quality concept developed in B2C-oriented literature in order to propose a holistic construct of LSQS. In the following, we develop those 'rights' that have been neglected in extant literature and thus need customization for our study:

- "the right amount, of the right product": Bouzaabia et al. (2013) do not explicitly include the element of out-of-stock situations or, in other words, non-availability. This seems surprising, as Saura et al. (2008) had identified availability as important measure, which is confirmed by field observations reflecting shoppers' 
reactions: ECR Europe (2003) calculated the cost of lost sales because of products being out-of-stock in the food retail sector at 4 billion $€$ per year. In line with Dabholkar et al. (1996), we have added products being out-of-stock in order to overcome this gap. In retail settings, the "right product" does not only refer to the individual article, but also to the bundle of products, or product assortment. Indeed, Huddlestone et al. (2009) found empirically that product assortment, along with price, quality, and employee service influence store satisfaction.

- "at the right price" refers, first of all, to the economic cost, i.e. the price of the purchased product, surprisingly absent in Bouzaabia's et al. (2013) measure, as well as in the one of Dabholkar's et al. (1996), whereas Hutcheson and Moutinho (1998) consider "low prices" among their supermarket choice criteria. Amplified by the economic crisis, shoppers' cost-consciousness is indeed retailers' number one trend to consider in logistics and supply chain management issues (Handfield et al., 2013). Huddlestone et al. (2009) found empirically that price, along with product assortment, quality, and employee service influence store satisfaction.

- "at the right price" refers also to the shopper's convenience, comfort, ergonomics, ease of use or other non-economic costs (Teller et al., 2011; Hutcheson and Moutinho, 1998; Dabholkar et al., 1996). Being the final logistician in the downstream chain, the shopper is sensitive towards the logistics dimension of merchandising, LSQS should thus explicitly include those elements or factors facilitating his "channel member" activities and tasks. The shop's opening hours clearly contribute to the shopper's convenience as considered by Dabholkar et al. (1996), whereas the authors neglected the store's geographical proximity that has a similar effect; that's why we have customised LSQS33, in line with Hutcheson and Moutinho (1998). As the shopper's convenience also applies to transportation to his residence and handling the purchased product/ packaging at home (Granzin et al., 1997, 2005), a holistic construct of LSQS should also include these items.

- "at the right time:" Bouzaabia's et al. (2013) items of timeliness only reflect the B2C setting. Indeed, time spent during the shopping experience, including waiting at the cash desk, also relates to timeliness.

We have developed 42 manifest variable underlying LSQS, as shown in Table 1, and space prevents us from providing further details about them. We are not presupposing any sub-constructs and will instead allow the EFA to suggest appropriate sub-constructs, which we can then use to purify the variables and refine the conceptual model. 
Tab. 2: LSQS variables

\begin{tabular}{|c|c|}
\hline Basic wording & $\begin{array}{c}\text { Logistics literature and LSQ constitutive } \\
\text { 'rights' } \\
\text { (Saura et al., 2008; Bouzaabia et al., 2013; } \\
\text { Mentzer et al. (1999/ 2001) }\end{array}$ \\
\hline $\begin{array}{l}\text { LSQS1: } \\
\text { In this store, information on product features } \\
\text { is sufficient. }\end{array}$ & quality of information ("with the right information") \\
\hline $\begin{array}{c}\text { LSQS2: } \\
\text { Information available on products is } \\
\text { completely accurate. }\end{array}$ & quality of information ("with the right information") \\
\hline $\begin{array}{c}\text { LSQS3: } \\
\text { Purchased products work very well. }\end{array}$ & condition ("in the right condition") \\
\hline $\begin{array}{l}\text { LSQS4: } \\
\text { This store offers high quality merchandise. }\end{array}$ & accuracy ("the right product") \\
\hline $\begin{array}{l}\text { LSQS5: } \\
\text { Deliveries arrive on the promised date. }\end{array}$ & accuracy; timeliness ("at the right time") \\
\hline $\begin{array}{c}\text { LSQS6: } \\
\text { Delivery of products purchased is always } \\
\text { correct. }\end{array}$ & condition ("in the right condition") \\
\hline $\begin{array}{c}\text { LSQS7: } \\
\begin{array}{c}\text { Product received from the store is } \\
\text { undamaged. }\end{array}\end{array}$ & condition ("in the right condition") \\
\hline $\begin{array}{c}\text { LSQS8: } \\
\begin{array}{c}\text { When this store promises to do something } \\
\text { by a certain time, it will do so. }\end{array}\end{array}$ & accuracy ("the right product at the right time") \\
\hline $\begin{array}{c}\text { LSQS9: } \\
\text { This store performs the right service the first } \\
\text { time. }\end{array}$ & accuracy ("the right product at the right time") \\
\hline $\begin{array}{c}\text { LSQS10: } \\
\text { Time between placing order and received } \\
\text { delivery is short. }\end{array}$ & timeliness ("at the right time") \\
\hline $\begin{array}{c}\text { LSQS11: } \\
\text { Time spent during the shopping experience, } \\
\text { including waiting time at counters and } \\
\text { checkouts, is at a reasonable low level for } \\
\text { the shopper. }\end{array}$ & timeliness ("at the right time") \\
\hline $\begin{array}{c}\text { LSQS12: } \\
\text { Employees in this store give prompt service } \\
\text { to shoppers. }\end{array}$ & $\begin{array}{c}\text { quality of contact personnel/ timeliness ("at the } \\
\text { right time") }\end{array}$ \\
\hline $\begin{array}{l}\text { LSQS13: } \\
\text { Employees in this store tell shoppers exactly } \\
\text { when services will be performed. }\end{array}$ & $\begin{array}{c}\text { quality of contact personnel/accuracy/ } \\
\text { convenience, non-economic cost ("at the right } \\
\text { cost") }\end{array}$ \\
\hline $\begin{array}{l}\text { LSQS14: } \\
\text { Employees in this store are never too busy } \\
\text { to respond to shopper's requests. }\end{array}$ & $\begin{array}{c}\text { quality of contact personnel/ timeliness ("at the } \\
\text { right time") }\end{array}$ \\
\hline $\begin{array}{c}\text { LSQS15: } \\
\text { When a shopper has a problem, this store } \\
\text { shows a real interest in solving it. }\end{array}$ & quality of contact personnel/ accuracy \\
\hline $\begin{array}{l}\text { LSQS16: } \\
\text { Store employees are able to find a solution } \\
\text { to any problem; employees in this store have } \\
\text { the knowledge to answer shoppers' } \\
\text { questions; the know-how and experience of } \\
\text { store employees are very adequate. }\end{array}$ & $\begin{array}{l}\text { quality of contact personnel/ accuracy ("the right } \\
\text { product") }\end{array}$ \\
\hline
\end{tabular}




\begin{tabular}{|c|c|}
\hline $\begin{array}{l}\text { LSQS17: } \\
\text { Store employees provide a great effort to } \\
\text { understand the shopper's situation; this } \\
\text { store gives shoppers individual attention. }\end{array}$ & $\begin{array}{c}\text { quality of contact personnel/ accuracy ("the right } \\
\text { product") }\end{array}$ \\
\hline $\begin{array}{l}\text { LSQS18: } \\
\text { The behaviour of employees in this store } \\
\text { instils confidence in shoppers. }\end{array}$ & $\begin{array}{l}\text { quality of contact personnel/ convenience, non- } \\
\text { economic cost ("at the right cost') }\end{array}$ \\
\hline $\begin{array}{l}\text { LSQS19: } \\
\text { Employees in this store are consistently } \\
\text { courteous and friendly with shoppers. }\end{array}$ & $\begin{array}{l}\text { quality of contact personnel/ convenience, non- } \\
\text { economic cost ("at the right cost") }\end{array}$ \\
\hline $\begin{array}{l}\text { LSQS20: } \\
\text { Employees of this store treat customers } \\
\text { courteously on the telephone. }\end{array}$ & $\begin{array}{l}\text { quality of contact personnel/ convenience, non- } \\
\text { economic cost ("at the right cost") }\end{array}$ \\
\hline $\begin{array}{l}\text { LSQS21: } \\
\text { Employees of this store are able to handle } \\
\text { shopper's complaints directly and } \\
\text { immediately; correction of delivered quality } \\
\text { discrepancies is satisfactory. }\end{array}$ & $\begin{array}{c}\text { quality of contact personnel/ accuracy ("the right } \\
\text { product") }\end{array}$ \\
\hline $\begin{array}{l}\text { LSQS22: } \\
\text { In the case of non-conforming product, there } \\
\text { are no problems when returning products; } \\
\text { this store willingly handles returns and } \\
\text { exchanges. }\end{array}$ & accuracy ("the right product") \\
\hline $\begin{array}{c}\text { LSQS23: } \\
\text { Shoppers feel safe in their transactions with } \\
\text { this store. }\end{array}$ & $\begin{array}{c}\text { accuracy/ convenience, non-economic cost ("at } \\
\text { the right cost") }\end{array}$ \\
\hline $\begin{array}{l}\text { LSQS24: } \\
\text { This store insists on secure, error-free sales } \\
\text { transactions and records. }\end{array}$ & accuracy ("the right product") \\
\hline $\begin{array}{c}\text { LSQS25: } \\
\text { Employees provide help with packing at } \\
\text { checkout. }\end{array}$ & $\begin{array}{l}\text { quality of contact personnel/ convenience, non- } \\
\text { economic cost ("at the right cost") }\end{array}$ \\
\hline $\begin{array}{c}\text { LSQS26: } \\
\text { This store has merchandise available when } \\
\text { the shoppers want it. }\end{array}$ & $\begin{array}{c}\text { availability ("the right amount of the right } \\
\text { product..") }\end{array}$ \\
\hline $\begin{array}{l}\text { LSQS27: } \\
\text { This store provides plenty of convenient } \\
\text { parking for shoppers. }\end{array}$ & $\begin{array}{c}\text { convenience, non-economic cost ("at the right } \\
\text { price") }\end{array}$ \\
\hline $\begin{array}{l}\text { LSQS28: } \\
\text { The store layout at this store makes it easy } \\
\text { for shoppers to find what they need. }\end{array}$ & $\begin{array}{c}\text { convenience, non-economic cost ("at the right } \\
\text { price") }\end{array}$ \\
\hline $\begin{array}{l}\text { LSQS29: } \\
\text { The store layout at this store makes it easy } \\
\text { for shoppers to move around in the store. }\end{array}$ & $\begin{array}{c}\text { convenience, non-economic cost ("at the right } \\
\text { price") }\end{array}$ \\
\hline $\begin{array}{l}\text { LSQS30: } \\
\text { Shopping ergonomics and merchandising } \\
\text { are satisfactory for shoppers, including } \\
\text { aisles' accessibility, quality of trolleys, easy } \\
\text { identification on the shelves and easy shelf } \\
\text { packaging. }\end{array}$ & $\begin{array}{l}\text { convenience, non-economic cost ("at the right } \\
\text { price") }\end{array}$ \\
\hline $\begin{array}{l}\text { LSQS31: } \\
\text { The product price as well as payment terms } \\
\text { seem correct to the shopper. }\end{array}$ & economic cost ("at the right price") \\
\hline $\begin{array}{l}\text { LSQS32: } \\
\begin{array}{c}\text { This store has operating hours convenient to } \\
\text { all shoppers. }\end{array}\end{array}$ & $\begin{array}{l}\text { convenience, non-economic cost ("at the right } \\
\text { price") }\end{array}$ \\
\hline
\end{tabular}




\begin{tabular}{|c|c|}
\hline $\begin{array}{l}\text { LSQS33: } \\
\text { The store's geographical proximity to your } \\
\text { residence is adequate for shoppers. }\end{array}$ & $\begin{array}{l}\text { convenience, non-economic cost ("at the right } \\
\text { price") }\end{array}$ \\
\hline $\begin{array}{l}\text { LSQS34: } \\
\text { This store accepts most major credit cards. }\end{array}$ & $\begin{array}{c}\text { convenience, non-economic cost ("at the right } \\
\text { price") }\end{array}$ \\
\hline $\begin{array}{c}\text { LSQS35: } \\
\text { This store offers its own credit card. }\end{array}$ & $\begin{array}{c}\text { convenience, non-economic cost ("at the right } \\
\text { price") }\end{array}$ \\
\hline $\begin{array}{l}\text { LSQS36: } \\
\text { Product and packaging characteristics (e.g. } \\
\text { weight, dimensions, unitization) are adapted } \\
\text { and convenient during the shopper's } \\
\text { transportation trip towards his residence. }\end{array}$ & $\begin{array}{c}\text { convenience, non-economic cost ("at the right } \\
\text { price") }\end{array}$ \\
\hline $\begin{array}{l}\text { LSQS37: } \\
\text { Product and packaging characteristics (e.g. } \\
\text { weight, dimensions, unitization) are adapted } \\
\text { and convenient before and during the } \\
\text { shopper's consumption process at his } \\
\text { residence. }\end{array}$ & $\begin{array}{c}\text { convenience, non-economic cost ("at the right } \\
\text { price") }\end{array}$ \\
\hline $\begin{array}{l}\text { LSQS38: } \\
\text { Product assortment, choice, range and } \\
\text { scope are satisfactory for shoppers. }\end{array}$ & accuracy ("the right amount of the right product") \\
\hline $\begin{array}{c}\text { LSQS39: } \\
\text { This store has modern-looking equipment } \\
\text { and fixtures. }\end{array}$ & $\begin{array}{l}\text { convenience, non-economic cost ("at the right } \\
\text { price") }\end{array}$ \\
\hline $\begin{array}{c}\text { LSQS40: } \\
\text { The physical facilities at this store are } \\
\text { visually appealing. }\end{array}$ & $\begin{array}{l}\text { convenience, non-economic cost ("at the right } \\
\text { price") }\end{array}$ \\
\hline $\begin{array}{l}\text { LSQS41: } \\
\text { Materials associated with this store's service } \\
\text { (such as shopping bags, catalogues, or } \\
\text { statements) are visually appealing. }\end{array}$ & $\begin{array}{c}\text { convenience, non-economic cost ("at the right } \\
\text { price") }\end{array}$ \\
\hline $\begin{array}{c}\text { LSQS42: } \\
\text { This store has clean, attractive, and } \\
\text { convenient public areas (restrooms, fitting } \\
\text { rooms). }\end{array}$ & $\begin{array}{l}\text { convenience, non-economic cost ("at the right } \\
\text { price") }\end{array}$ \\
\hline
\end{tabular}

Source: Authors

\section{The satisfaction construct}

It is widely accepted that perceived general service quality has an impact on customer satisfaction (Dabholkar and Overby, 2005), which in turn leads to later behaviours towards the service firm, including loyalty (Andreassen and Lindestad, 1998; Wong and Sohal, 2003). LSQS strives, together with marketing and other business domains, for consumer satisfaction and loyalty, on both transaction-specific and long-run cumulative levels (Zhang et al., 2005), in order to guarantee the firm's competitive advantage (Innis and Lalonde, 1994). Shopper satisfaction is an attitude, unlike shopper loyalty, which is a purchase behaviour (Griffin, 1996), or a combination of attitude and behaviour (Jones and Taylor, 2007).

Based upon a multi-method study, Giese and Cote (2000) define satisfaction as a response (cognitive or affective) that pertains to a particular focus (i.e. purchase experience and/ or the associated product) and occurs at a certain time (i.e. postpurchase, post-consumption). We have developed eight manifest variables underlying SATIS shown in Table 3. Items referring to consumer satisfaction in 
food retailing as proposed by Huddlestone et al. (2009) seem the most valuable for our study, even if Bouzaabia et al. (2013) and Saura et al. (2008) proposed explicit LSQ constructs. Whereas Saura et al. (2008) analyse a B2B relationship between manufacturers and their logistics/ distribution service providers, Bouzaabia et al. (2013) apply their measures to hypermarket shoppers.

Tab. 3: Satisfaction variables

\begin{tabular}{|c|c|}
\hline Basic wording & Origin \\
\hline $\begin{array}{l}\text { SATIS1: } \\
\text { Overall, the shopper is satisfied with the } \\
\text { services provided by this store. }\end{array}$ & $\begin{array}{l}\text { Bouzzabia et al. (2013): satisfaction with } \\
\text { B2C LSQ. }\end{array}$ \\
\hline $\begin{array}{c}\text { SATIS2: } \\
\text { The shopper wishes more of his stores } \\
\text { were like this one. }\end{array}$ & $\begin{array}{c}\text { Saura et al. (2008): satisfaction with B2B } \\
\text { LSQ }\end{array}$ \\
\hline $\begin{array}{c}\text { SATIS3: } \\
\text { The shopper is delighted with the overall } \\
\text { retail service relationship. }\end{array}$ & $\begin{array}{c}\text { Saura et al. (2008): satisfaction with B2B } \\
\text { LSQ }\end{array}$ \\
\hline $\begin{array}{c}\text { SATIS4: } \\
\begin{array}{c}\text { Compared to other stores, the shopper is } \\
\text { very satisfied with this store. }\end{array}\end{array}$ & $\begin{array}{c}\text { Bettencourt (1997); Huddlestone et al. } \\
\text { (2009): consumer satisfaction in food } \\
\text { retailing }\end{array}$ \\
\hline $\begin{array}{c}\text { SATIS5: } \\
\begin{array}{c}\text { Based on all experiences with this store, } \\
\text { the shopper is very satisfied. }\end{array}\end{array}$ & $\begin{array}{c}\text { Bettencourt (1997); Huddlestone et al. } \\
\text { (2009): consumer satisfaction in food } \\
\text { retailing }\end{array}$ \\
\hline $\begin{array}{c}\text { SATIS6: } \\
\text { In general, the shopper is satisfied with this } \\
\text { store. }\end{array}$ & $\begin{array}{l}\text { Bettencourt (1997); Huddlestone et al. } \\
\text { (2009): consumer satisfaction in food } \\
\text { retailing }\end{array}$ \\
\hline $\begin{array}{l}\text { SATIS7: } \\
\text { Overall, the shopper is satisfied with the } \\
\text { purchased products and related brands }\end{array}$ & $\begin{array}{c}\text { Adapted from Bouzzabia et al. (2013) to } \\
\text { brands. }\end{array}$ \\
\hline $\begin{array}{c}\text { SATIS8: } \\
\text { The shopper wishes more of his brands } \\
\text { were like those purchased here. }\end{array}$ & Adapted from Saura et al. (2008) to brands. \\
\hline
\end{tabular}

Source: Authors

\section{The loyalty construct}

Dick and Basu (1994) define loyalty as a combination of repeat purchase levels (repeat patronage behaviour) and relative attitude (level of attachment). Jones and Taylor (2007) empirically found that loyalty for the specific domain of services has two dimensions: a behavioural element and a combined attitude/ cognitive element. The first one consists of repurchase intentions, switching intentions and exclusive purchasing intentions, whereas the second one translates consumers' strength of preference, advocacy, altruism, willingness to pay more and identification with the service provider.

Following Wong and Sohal (2003, p. 497) loyalty in retail settings occurs when shoppers or other customers repeatedly purchase a good or service over time and hold favourable attitudes towards a good or service or towards the company supplying the good or service, e.g. the retailer store. Hence, we have developed 43 
manifest variables underlying LOYAL, which is our ultimate output or resultant construct, and they are shown in Table 4.

Tab. 4: Loyalty variables

\begin{tabular}{|c|c|c|}
\hline Basic wording & Dimension & Origin \\
\hline $\begin{array}{l}\text { LOYAL1: } \\
\text { This store is always the shopper's first choice. }\end{array}$ & attitude (store) & $\begin{array}{c}\text { Bouzzabia et al. } \\
\text { (2013) }\end{array}$ \\
\hline $\begin{array}{l}\text { LOYAL2 } \\
\begin{array}{c}\text { The shopper prefers this store to other retailers in this } \\
\text { category. }\end{array}\end{array}$ & attitude (store) & $\begin{array}{l}\text { Mitra and Lynch } \\
(1995)\end{array}$ \\
\hline $\begin{array}{c}\text { LOYAL3: } \\
\begin{array}{c}\text { The shopper would rank this store as } n^{\circ} 1 \text { amongst } \\
\text { the other retailers. }\end{array}\end{array}$ & attitude (store) & $\begin{array}{l}\text { Mitra and Lynch } \\
\text { (1995) }\end{array}$ \\
\hline $\begin{array}{l}\text { LOYAL4: } \\
\text { This store provides the best service among the } \\
\text { alternatives the shopper has. }\end{array}$ & attitude (store) & $\begin{array}{l}\text { Mitra and Lynch } \\
(1995)\end{array}$ \\
\hline $\begin{array}{l}\text { LOYAL5: } \\
\text { Compared to this store, there are few alternatives with } \\
\text { whom the shopper would be satisfied. }\end{array}$ & attitude (store) & $\begin{array}{l}\text { Mitra and Lynch } \\
(1995)\end{array}$ \\
\hline $\begin{array}{l}\text { LOYAL6: } \\
\text { The shopper makes an effort to use the retail store for } \\
\text { retail shopping needs. }\end{array}$ & attitude (store) & $\begin{array}{l}\text { Bettencourt } \\
(1997)\end{array}$ \\
\hline $\begin{array}{c}\text { LOYAL7: } \\
\text { The shopper deals with the retail store, because he } \\
\text { wants to, not because he has to. }\end{array}$ & attitude (store) & Barnes (1997) \\
\hline $\begin{array}{l}\text { LOYAL8: } \\
\begin{array}{c}\text { Sometimes, shoppers get a feeling of being trapped in } \\
\text { dealing with the retail store. }\end{array}\end{array}$ & attitude (store) & Barnes (1997) \\
\hline $\begin{array}{l}\text { LOYAL9: } \\
\begin{array}{c}\text { The shopper is likely to pay a little bit more for using } \\
\text { this store. }\end{array}\end{array}$ & attitude (store) & $\begin{array}{l}\text { Zeithaml et al. } \\
\qquad(1996)\end{array}$ \\
\hline $\begin{array}{l}\text { LOYAL10: } \\
\text { Price is not an important factor in the shopper's } \\
\text { decision to remain with this store. }\end{array}$ & attitude (store) & $\begin{array}{l}\text { Zeithaml et al. } \\
\qquad(1996)\end{array}$ \\
\hline $\begin{array}{l}\text { LOYAL11: } \\
\text { If the store were to raise the price by } 10 \% \text {, the } \\
\text { shopper would likely remain. }\end{array}$ & attitude (store) & $\begin{array}{l}\text { Zeithaml et al. } \\
\qquad(1996)\end{array}$ \\
\hline $\begin{array}{l}\text { LOYAL12: } \\
\text { The shopper is willing to pay more for this store's } \\
\text { services. }\end{array}$ & attitude (store) & $\begin{array}{l}\text { Zeithaml et al. } \\
\qquad(1996)\end{array}$ \\
\hline $\begin{array}{l}\text { LOYAL13: } \\
\begin{array}{c}\text { The shopper says positive things about the store to } \\
\text { other people. }\end{array}\end{array}$ & attitude (store) & $\begin{array}{l}\text { Zeithaml et al. } \\
\text { (1996) }\end{array}$ \\
\hline $\begin{array}{l}\text { LOYAL14: } \\
\text { The shopper recommends this store to someone who } \\
\text { asks his advice. }\end{array}$ & attitude (store) & $\begin{array}{l}\text { Zeithaml et al. } \\
\qquad(1996)\end{array}$ \\
\hline $\begin{array}{l}\text { LOYAL15: } \\
\text { The shopper encourages friends and relatives to buy } \\
\text { at this store. }\end{array}$ & attitude (store) & $\begin{array}{l}\text { Zeithaml et al. } \\
\qquad(1996)\end{array}$ \\
\hline $\begin{array}{l}\text { LOYAL16: } \\
\text { The store the shopper uses says a lot about who he } \\
\text { is. }\end{array}$ & attitude (store) & $\begin{array}{l}\text { Ganesh et al. } \\
\quad(2000)\end{array}$ \\
\hline
\end{tabular}




\begin{tabular}{|c|c|c|}
\hline $\begin{array}{l}\text { LOYAL17: } \\
\text { The shopper thinks of the store as "his" shop. }\end{array}$ & attitude (store) & $\begin{array}{l}\text { Ganesh et al. } \\
\quad(2000)\end{array}$ \\
\hline $\begin{array}{l}\text { LOYAL18: } \\
\begin{array}{l}\text { Overall, the shopper considers the store's service to } \\
\text { be excellent. }\end{array}\end{array}$ & attitude (store) & $\begin{array}{l}\text { Dabholkar et al. } \\
(2000)\end{array}$ \\
\hline $\begin{array}{l}\text { LOYAL19: } \\
\text { The shopper will probably use this store again. }\end{array}$ & $\begin{array}{l}\text { behaviour } \\
\text { (store) }\end{array}$ & $\begin{array}{l}\text { Jones and } \\
\text { Taylor (2007) }\end{array}$ \\
\hline $\begin{array}{l}\text { LOYAL20: } \\
\text { The shopper intends to repurchase from this store } \\
\text { again in the future. }\end{array}$ & $\begin{array}{l}\text { behaviour } \\
\text { (store) }\end{array}$ & $\begin{array}{l}\text { Jones and } \\
\text { Taylor (2007) }\end{array}$ \\
\hline $\begin{array}{l}\text { LOYAL21: } \\
\text { If all the other attributes are similar (product, } \\
\text { quality,..), the shopper will buy always to this store by } \\
\text { their value-adding service (timeliness, condition and } \\
\text { accuracy of the order, quality of information, } \\
\text { availability, quality of contact personnel, convenience, } \\
\text { comfort, ergonomics). }\end{array}$ & $\begin{array}{l}\text { behaviour } \\
\text { (store) }\end{array}$ & $\begin{array}{l}\text { Saura et al. } \\
(2008)\end{array}$ \\
\hline $\begin{array}{c}\text { LOYAL22: } \\
\text { Shopper's rating that he would switch to another store: } \\
\text { unlikely..likely } \\
\text { improbable.. probable } \\
\text { no chance.. certain }\end{array}$ & $\begin{array}{l}\text { behaviour } \\
\text { (store) }\end{array}$ & $\begin{array}{l}\text { Bansal and } \\
\text { Taylor (1999) }\end{array}$ \\
\hline $\begin{array}{l}\text { LOYAL23: } \\
\text { The shopper purchases exclusively at this store for a } \\
\text { given product. }\end{array}$ & $\begin{array}{l}\text { behaviour } \\
\text { (store) }\end{array}$ & $\begin{array}{c}\text { Jones and } \\
\text { Taylor (2007) }\end{array}$ \\
\hline $\begin{array}{l}\text { LOYAL24 to LOYAL43 have been adapted to brands } \\
\text { (starting from and in-line with LOYAL1 to LOYAL23; } \\
\text { except for LOYAL4, LOYAL12 and LOYAL18 that only } \\
\text { apply to retailers). }\end{array}$ & & \\
\hline
\end{tabular}

Source: Authors

\section{First conclusions and next steps}

This paper has discussed the development of a research study investigating the effect logistics service quality for consumers, or LSQS, has on their overall in-store shopping experience, satisfaction and loyalty towards grocery retailers. The extensive literature review has provided over 40 variables of interest for both LSQS and loyalty, and almost ten variables of satisfaction. An empirical study will be undertaken to validate and purify these variables across three European contexts of France, UK and Germany. The study should contribute theoretically by considering these important issues in a fresh light, focussing on the consumer's perspective as opposed to usual B2B perspectives, and will also look for differences and similarities among the three primary European markets, which might suggest different approaches despite being in a pan-European trading environment. For practitioners, the study should contribute by providing a battery of validated and tested LSQS variable that they can incorporate into their customer service strategy in order to generate increased satisfaction and loyalty in a marketplace that is currently 
being driven by discount retailers and low prices and ignoring some basic service criteria. This contribution represents one module of a broad on-going European research programme that also includes online dimensions of shopping behaviour and channel strategies (Grant and Philipp, 2014).

\section{References}

ACCESS 6 (2013), "The German Market”, http://www.access6.eu/country-profile/germanmarket (accessed 21 March 2014).

ANDREASSEN T.W., LINDESTAD A. (1998), "Customer loyalty and complex services: the impact of corporate image on quality, customer satisfaction and loyalty for customers with varying degrees of service expertise", International Journal of Service Industry Management, vol. 9, n. 1, pp. 7-23.

BANSAL H.S., TAYLOR S.F. (1999), "The service provider switching model: a model of consumer switching behaviour in the services industry", Journal of Service Research, vol. 2, n. 2, pp. 200-218.

BARNES J.G. (1997), "Closeness, strength, and satisfaction: examining the nature of relationships between providers of financial services and their retail customers", Psychology and Marketing, vol. 14, n. 8, pp. 765-790.

BEI L.T., CHIAO Y.C. (2001), "An integrated model for the effects of perceived product, perceived service quality, and perceived price fairness on consumer satisfaction and loyalty", Journal of Consumer Satisfaction, Dissatisfaction and Complaining Behavior, vol. 14, pp. 125-140.

BETTENCOURT L.A. (1997), "Customer voluntary performance: customers as partners in service delivery", Journal of Retailing, vol. 73, n. 3, pp. 383-406.

BIENSTOCK C.C., ROYNE M.B., SHERREL D., STAFFORD T.F. (2008), "A expanded model of logistics service quality: incorporating logistics information technology", International Journal of Production Economics, vol. 113, n. 1, pp. 5-22.

BIENSTOCK CC., MENTZER J.T., BIRD M.M. (1997), "Measuring physical distribution service quality", Journal of the Academy of Marketing Science, vol. 25, n. 1, pp. 3144.

BOUZAABIA R., BOUZAABIA O., CAPATINA A. (2013), "Retail Logistics service quality: a cross-cultural survey on customer perceptions", International Journal of Retail \& Distribution Management, vol. 41, n. 8, pp. 627-647.

CHURCHILL G.A. (1979), "A Paradigm for Developing Better Measures of Marketing Constructs", Journal of Marketing Research, vol. 16 (February), pp. 64-73.

COLIN J., FABBE-COSTES N. (1995), "Les stratégies développées par les prestataires logistiques confrontés à la tentation des chargeurs de réintégrer des opérations logistiques", $7^{\text {th }}$ world conference on transport research, Sidney.

DABHOLKAR P.A., THORPE D.I., RENTZ J.O. (1996), "A measure of service quality for retail stores: scale development and validation", Journal of the Academy of Marketing Science, vol. 24, n. 1, pp. 3-16.

DABHOLKAR P.A., OVERBY J.W. (2005), "Linking process and outcome to service quality and customer satisfaction evaluations", International Journal of Service Industry Management, vol. 16, n. 1, pp. 10-27.

DANAHER P.J., MATTSON J. (1994), "Customer satisfaction during the service delivery process", European Journal of Marketing, vol. 28, n. 5, pp. 5-16. 
DICK A.S., BASU K. (1994), "Customer loyalty: toward an integrated conceptual framework", Journal of the Academy of Marketing Science, vol. 22, n. 2, pp. 99-113.

DUNN S.C., SEAKER R.F., WALLER M.A. (1994), "Latent Variables in Business Logistics Research: Scale Development and Validation", Journal of Business Logistics, vol. 15, n. 2, pp. 145-172.

FERNIE J., GRANT D.B. (2008), “On-shelf availability: The case of a UK grocery retailer”, International Journal of Logistics Management, vol. 19, n. 3, pp. 293-308.

GANESH J., ARNOLD M.J., REYNOLDS K.E. (2000), "Understanding the customer base of service providers: an examination of the differences between switchers and stayers", Journal of Marketing, vol. 64, n. 3, pp. 65-87.

GIESE J.L., COTE J.A. (2000), "Defining consumer satisfaction", Academy of Marketing Science Review [http://amsreview.org/articles/giese01-2000.pdf], pp. 1-24.

GÖPFERT I., WEHBERG G. (1995), Ökologieorientiertes Logistik-Marketing, W. Kohlhammer, Stuttgart.

GRANT D.B., PHILIPP B. (2014), "Does B2C online logistics service quality impact urban logistics?", $4^{\text {th }}$ colloquium of urban logistics (LEMNA/ university), Nantes.

GRANT D.B. (2003), A Study of Customer Service, Customer Satisfaction and Service Quality in the Logistics Function of the UK Food Processing Industry PhD thesis, Edinburgh.

GRANT D.B. (2012), Logistics Management. Harlow UK, Pearson Education.

GRANZIN K.L., PAINTER J.J., VALENTIN E.K. (1997), "Consumer logistics as a basis for segmenting retail markets: an exploratory inquiry", Journal of Retailing and Consumer Services, vol. 4, n. 2, pp. 99-107.

GRANZIN K.L., PAINTER J.J., BAHN K.D. (2005. "An empirical test of households' participation in the distribution supply chain process", Journal of Marketing Channels, vol. 12, n. 4, pp. 67-89.

GRIFFIN J. (1996), “The Internet's expanding role in building customer loyalty", Direct Marketing, vol. 59, n. 7, pp. 50-53.

HANDFIELD R., STRAUBE F., PFOHL H.C., WIELAND A. (2013), Trends and strategies in logistics and supply chain management DVV Media Group, Bremen.

HARRIS K., HARRIS R., BARON S. (2001), "Customer participation in retail service: lessons from Brecht". International Journal of Retail \& Distribution Management, vol. 29 , n. 8, pp. 359-369.

HUDDLESTON P., WHIPPLE J., MATTICK R.N., LEE S.J. (2009), “Customer satisfaction in food retailing: comparing specialty and conventional grocery stores", International Journal of Retail \& Distribution Management, vol. 37, n. 1, pp. 63-80.

HUTCHESON G.D., MOUTINHO L. (1998), "Measuring preferred store satisfaction using consumer choice criteria as a mediating factor", Journal of Marketing Management, vol. 14, n. 7, pp. 705-720.

IGD (2014), "Retail Fact Sheet", http://www.igd.com/ [Accessed 26 March 2014].

INNIS D.E., LA LONDE B.J. (1994), "Customer Service: The Key to Customer Satisfaction, Customer Loyalty, and Market Share", Journal of Business Logistics, vol. 15, n. 1, pp. 127.

JONES T., TAYLOR S.F. (2007), "The conceptual domain of service loyalty: how many dimensions?" Journal of Services Marketing, vol. 21, n. 1, pp. 36-51.

KÄMÄRÄINEN V., PUNAKIVI M. (2002), "Developing Cost-effective Operations for the eGrocery Supply Chain", International Journal of Logistics: Research and Applications, vol. 5, n. 3, pp. 286-298. 
KLUMPP M., JASPER A. (2008), "Success Factors for Retail Logistics in an E-commerce environment", Sineuropean Engineering Research Journal, vol. 1, pp. 63-68.

LA LONDE B.J., ZINSZER P.H. (1991), "Customer service: meaning and measurement", in Ballou, R. (ed.), Logistica empresarial, control y planificacion, Ediciones Diaz de Santos, Madrid.

LIU X., HE M., GAO F., XIE P. (2008), "An empirical study of online shopping customer satisfaction in China: a holistic perspective", International Journal of Retail \& Distribution Management, vol. 36, n. 11, pp. 919-940.

MCKINNON A.C., MENDES D., NABABTEH M. (2007), 'In-store Logistics: an Analysis of On-shelf Availability and Stockout Responses for Three Product Groups' International Journal of Logistics: Research and Application, vol. 10, n. 3, pp. 251268.

MENG Q., GRANT D., FERNIE J., (2012), "Improving on-shelf availability and out-ofstocks in non-food retail”, Supply Chain Forum - An International Journal, vol. 13, n. 4, pp. 4-12.

MENTZER J.T., FLINT D.J., KENT J.L. (1999), "Developing a Logistics Service Quality Scale", Journal of Business Logistics, vol. 20, n. 1, pp. 9-32.

MENTZER J.T., FLINT D.J., HULT G.T. (2001), "Logistics Service Quality as a SegmentCustomized Process", Journal of Marketing, vol. 65 (October), pp. 82-104.

MITRA A., LYNCH J. (1995), "Toward a reconciliation of market power and information theories of advertising effects on price elasticity", Journal of Consumer Research, vol. 21, n. 4, pp. 644-660.

MYERS H., ALEXANDER N. (2007), "The role of retail internationalisation in the establishment of a European retail structure", International Journal of Retail \& Distribution Management, vol. 35, n. 1, pp. 6-19.

NOVACK R.A., RINEHART L.M., LANGLEY C.J. (1994), “An internal assessment of logistics value", Journal of Business Logistics, vol. 15, n. 1, pp. 113-152.

PARASURAMAN A., ZEITHAML V.A., BERRY L.L. (1988), "SERVQUAL: a multipleitem scale for measuring customer perceptions of service quality", Journal of Retailing, vol. 64, n. 1, pp. 12-40.

PARASURAMAN A., ZEITHAML V.A., BERRY L.L. (1985), "A Conceptual Model of Service Quality and Its Implications for Future Research", Journal of Marketing, vol. 49, (Fall), pp. 41-50.

PERKINS B. (2001), "The European Retail Grocery Market Overview", British Food Journal, vol. 103, n. 10, pp. 744-748.

PERRAULT W.D., RUSS F.A. (1976), "Physical distribution service in industrial purchase decisions", Journal of Marketing, vol. 40, n. 2, pp. 3-10.

RAHMAN S. (2006), "Quality management in logistics: an examination of industry practices", Supply Chain Management: An International Journal, vol. 11, n. 3, pp. 233-240.

SAURA I.G., FRANCES D.S., CONTRI G.B., BLASCO M.F. (2008), "Logistics service quality: a new way to loyalty", Industrial Management \& Data Systems, vol. 108, n. 5, pp. 650-668.

SHARMA A.G., GREWAL D., LEVY M. (1995), "The Customer Satisfaction/Logistics Interface", Journal of Business Logistics, vol. 16, n. 2, pp. 1-21.

TELLER C., KOTZAB H., GRANT D.B. (2006), "The consumer direct services revolution in grocery retailing: An exploratory investigation”, Managing Service Quality, vol. 16, n. 1, pp. 78-96. 
TELLER C., KOTZAB H., GRANT D.B. (2012), "The relevance of shopper logistics for consumers of store-based retail formats", Journal of Retailing and Consumer Services, vol. 19, n. 1, pp. 59-66.

THAI V. (2013), "logistics service quality: conceptual model and empirical evidence", International Journal of Logistics: Research \& Applications, vol. 16, n. 2, pp. 114131.

THIRUMALAI S., SINHA K.K. (2004), "Customer satisfaction with order fulfillment in retail supply chains: implications of product type in electronic B2C transactions", Journal of Operations Management, vol. 23, n. 3-4, pp. 291-303.

THOMASSON E. (2014), "German grocers push upmarket in cut-throat retail race", http://www.reuters.com/article/2014/02/14/us-retail-germany-analysisidUSBREA1D0OJ20140214 [accessed 15 March 2014].

WONG A., SOHAL A. (2003), "Service quality and customer loyalty perspectives on two levels of retail relationships", Journal of Services Marketing, vol. 17, n. 5, pp. 495513.

XING Y., GRANT D.B. (2006), "Developing a framework for measuring physical distribution service quality of multi-channel and pure player internet retailers", International Journal of Retail \& Distribution Management, vol. 34, n. 4/5, pp. 278289.

XING Y., GRANT D.B., MCKINNON A.C., FERNIE J. (2011), "The Interface between retailers and logistics service providers in the online market". European Journal of Marketing, vol. 45, n. 3, pp. 334-357.

ZEITHAML V.A., BERRY L.L., PARASURAMAN A. (1996), "The behavioural consequences of service quality", Journal of Marketing, vol. 60, n. 2, pp. 31-46.

ZHANG Q., VONDEREMBSE M.A., LIM J.S., (2005), "Logistics flexibility and its impact on customer satisfaction", International Journal of Logistics Management, vol. 16, n. 1, pp. 71-95. 
